\title{
Validating a Model of Change Readiness among Malaysian School Teachers: A Structural Equation Modeling Approach
}

\author{
Banu Ramanan and Mua'azam Bin Mohamad \\ School of Education and Modern Languages \\ University Utara Malaysia
}

\begin{abstract}
This study aimed to validate the instrument of change readiness to improve teacher competencies. The tool was divided into four main dimensions, namely, change self-efficacy, discrepancy, personal valence, and organizational valence using verification factor analysis (CFA). The study utilized a cross-sectional design involving 383 primary and secondary school teachers selected through stratified random sampling from eastern coastal states in Malaysia. The instrument for this study used a seven-point Likert scale. The hypothesis was tested with a measurement model using IBM SPSS SEM-AMOS version 25.0. Four items identified as having low factor loadings were dropped. This finding indicates that the final measurement model is compatible with the data obtained. This model meets the requirements of reliability and constructs validity, convergent validity, and discriminant validity. In conclusion, this measurement model could measure the degree of change readiness among school teachers to become a competent teacher. Change is a crucial element in the teaching profession as the education world had to face ongoing changes rapidly. The findings of this study have implications for the importance of teacher readiness to change to become a competent teacher who plays a crucial role in student achievement indirectly.
\end{abstract}

Keywords: Measurement model; Readiness change; competency; verification factor analysis; school teachers

\section{Introduction}

Transformations in technology, mainly in Industrial Revolution 4.0 (IR 4.0), created intense competition, especially in the education system (Schwab \& Davis, 2018). Besides, the sophistication of technologies such as Artificial Intelligence and the Internet of Things requires a teaching approach that meets the needs of current trends (Darling Hammond, 2017; Hinton, 2018). 


\section{The Gap of the Study}

Teachers play a crucial role in educating, training, and providing individuals with knowledge that enhance students outcome (Darling-Hammond, 2017; Schunk \& DiBenedetto, 2016). As such, teachers need to adapt to new developments and face the challenges of implementing change. But how? Here change management strategies could help. Initially, the concept of evolution is widely used in the management field. Contemporary research uses the changing concept in order to know change readiness among organization members to adapt to the new changes. Since the change management strategy model could apply to other fields, therefore we sought further to understand individual change readiness through the eyes of education. Using a change readiness tool will help bridge the gap between change management and education. The integration of knowledge from management to education will provide new knowledge in everyday life. Besides that, unfortunately, existing studies generally respond to staff readiness in the private sector (Armenakis, Harris, \& Mossholder, 1993; Holt, Armenakis, \& Harris, 2007) whereas the public sector gets less attention (Sawitri \& Wahyuni, 2018) especially in the education field. The lack of empirical studies on the readiness of teacher change to became competent teachers has never been investigated in previous studies. Therefore this research will be a foundation for the responsible authorities to design more targeted change programs to enhance teacher change readiness.

\section{Change Readiness}

The readiness of change creates the positive energy that a teacher needs and is an early step in the process of transforming the educational system (Armenakis et al., 1993; Vakola, 2014). In this regard, to support the success of educational change initiatives by Ministry of Education Malaysia (MOE) in Malaysia Education Blueprint 2013-2025 as stated in eleven shift (i.e., giving evenhanded access to universal quality training, to guarantee that each understudy is capable in both Bahasa Malaysia and English, to deliver Malaysians who acknowledge esteem, showing change as a calling of decision, guarantee elite pioneers are set in each school, to empower the state, district education offices and also schools to give explicit arrangements dependent on their needs, using ict to improve the nature of learning in Malaysia, change of instruction conveyance capacities and abilities, work together with guardians, networks and the private division generally, boost understudy accomplishment for each dollar.

Increment straightforwardness in open responsibility to transform the system focus needs to be placed on in-service teachers' change readiness. According to the Educational Planning and Research Division (MOE, 2018) the total enrollment of in-service teachers is 240,101 at primary and 183,465 at secondary school. Its shows almost half a million teachers act as a mediator to embrace \& uphold the milestones to achieve the goal. Nevertheless, change alone will take time. Therefore, the readiness of change will ensure to determine how ready the teachers before changes in the education field implemented (Holt et al., 2007).

The founder of change readiness theory (Armenakis et al., 1993) readiness is a precursor to resistance or acceptance behavior. Measuring the level of readiness 
to accept significant changes needs to be done so that school administrators and the education ministry can identify the gaps that exist between their expectations of change initiatives. This measurement helps to identify if there are significant gaps in teachers and could help to take appropriate action so that teachers are prepared and accepting changes. The readiness of change is widely used in management and health areas (Berger \& Hudmon, 1997; Haffar, AlKaraghouli, \& Ghoneim, 2013; Neves, 2009). However, in the field of education, especially to know the level of readiness of teacher change in education, the transformation has not been made. Therefore, the validation factor analysis (CFA) should be performed to ensure that this measurement model matches the available data. Besides, this analysis will help to gauge the level of readiness of teachers to become competent in the process of elevating Malaysian educational outcomes to international standards.

\section{Purpose of the Study}

This study aims to determine the validity and reliability of the proposed level of change readiness model to enhance teacher competence. The change readiness model comprises four subconstructs, namely, change self-efficacy, discrepancy, personal valence, and organizational valence as the underlying primary dimension of change readiness construct. To address the research objective, the study used a four-factor model of change readiness synthesized from (Holt, Armenakis, Feild, \& Harris, 2007). Based on the above objective, the research question is as follows:

$R Q 1$. Is the measurement model for the change readiness level of Malaysian school teachers valid and reliable?

Thus, based on the conceptual framework (Figure1), research objective and research question the following hypotheses were formulated:

H1. All the four models for the level of change readiness model of Malaysian school teachers are valid and reliable.

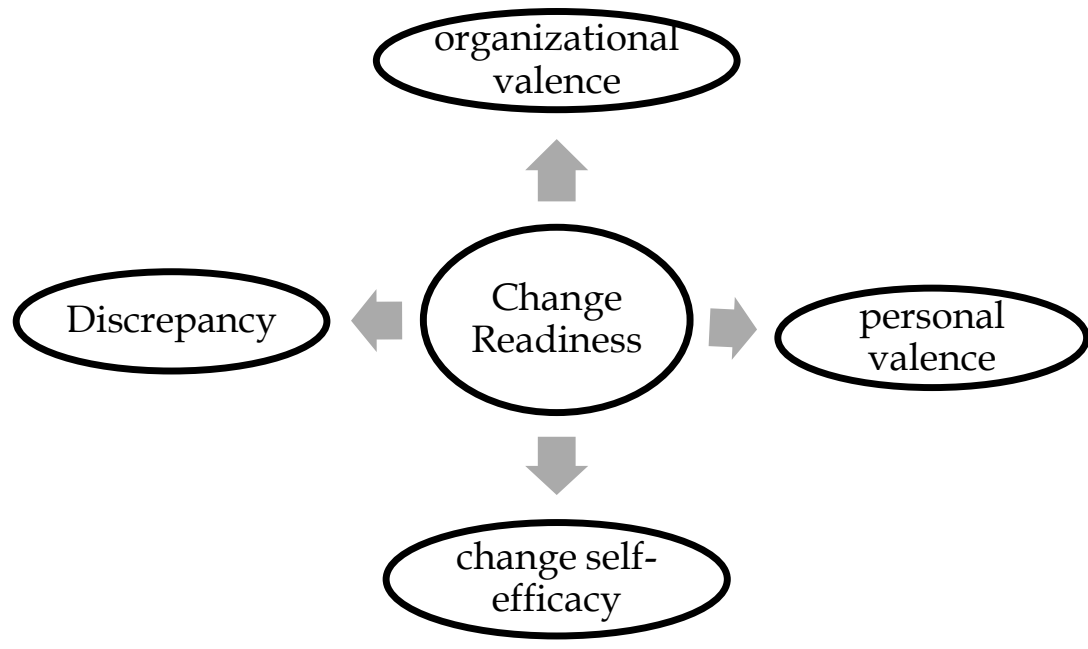

Figure 1: Model of Individual Change Readiness (Holt, Armenakis, Feild \& Harris, (2007) 


\section{Measurement Model}

The hypothesized measurement model contains change readiness (KP) as a second-level construct, which measured by four first-level constructs, namely, change self-efficacy, discrepancy, personal valence, and organizational valence, as shown in Figure 2.0. These four factors are defined in Holt et al., (2007) change model and each construct are measured with specific items as suggested by him.

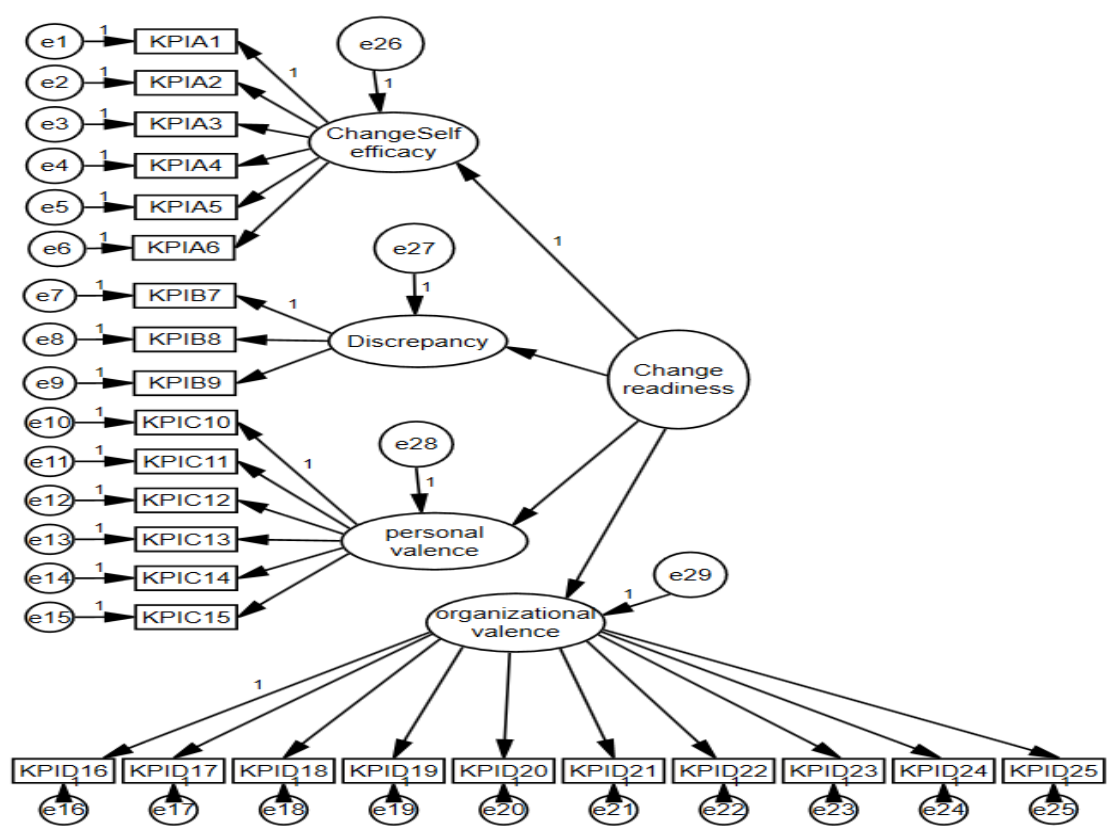

Figure 2: Preparedness measurement model for Level of Change Readiness Among Malaysian School Teachers.

\section{Methodology}

The design used in the study is a cross-sectional survey method to gather information from the teachers. The cross-sectional method is the best way for this study because it helps to gather responses from a broad educational field. The instruments were able to distribute widely in a short period (Holt et al., 2007). Teachers from primary and secondary schools, particularly national schools from eastern coastal states involved in this study. National primary schools and national secondary schools are grouped by city and rural category by state. A total of 383 respondents were selected through a random sampling technique based on the states of Kelantan, Terengganu, and Pahang. According to (Creswell, 2013; Hair, Black, Babin, \& Anderson, 2014), this sampling technique is an appropriate technique to enhance the representativeness of the sample in the study population. Since the study carried out among national government schools, a permission letter was sought from the Ministry of Education and State level Education Departments. The survey questionnaire was 
distributed according to the chosen school by systematic random sampling. The researcher personally visited the respondents during working hours with permission and was asked to complete the questionnaire. The questionnaire was translated in the Malay language as Bahasa Malaysia is the standard national language which is used by all the teachers in government. The respondents were informed about the confidentiality and purpose of the study. A period of two weeks of the time was given for the respondents to complete the questionnaires. The researcher personally dispersed a total of 583 questionnaires, but only 522 of a questionnaire that was returned and 383 are usable questionnaires.

This study used seven Likert scale instruments adapted from (Holt et al., 2007). The questionnaire has initially been published in English, but the backtranslation method was developed, as suggested by (Brislin, 1973). At least two independent translators did the first translation from the original language to the Malay language. And then, the primary translation independently backtranslated from the Malay language to English to check the accuracy of the translation. It is because the researcher using a questionnaire which was developed and tested across different language and culture so this will help to make sure that the questionnaires in different languages are assessing the equivalent construct with an equivalent metric. It is the best method to ensure that a translated measure is equivalent to the original questionnaire (Beaton, Bombardier, Guillemin \& Ferraz, 2000) Furthermore, a total of five experts from the field use to validate the questionnaire. It is to ensure the translated questionnaire is measured whether the items are adequately measuring the construct intended to assess and also whether the items are sufficient to measure the domain of interest. Responses were measured on a seven-point scale with $1=$ strongly disagree, $2=$ disagree, $3=$ somewhat disagree, $4=$ neutral, $5=$ somewhat agree, $6=$ agree, $7=$ strongly agree. The questionnaire used consisted of two sections. Part A collects demographic data, and Part B gathers information on the level of individual change readiness. Table 1 shows more information in detail about dimensions that used to measure the level of change readiness among school teachers which is separated according to four main constructs namely Change self-efficacy (6) items, Discrepancy (3) items, Personal valence (6) items, and Organizational valence (10) items.

Table 1: Dimensions, numbers of questions and numbers of the items of Individual Change Readiness

\begin{tabular}{|l|c|c|}
\hline Dimensions & Numbers of Questions & Numbers of Items \\
\hline Change self-efficacy & $1-6$ & 6 \\
\hline Discrepancy & $7-9$ & 6 \\
\hline Personal valence (6) & $10-15$ & 10 \\
\hline Organizational valence & $16-25$ & \multicolumn{2}{|c|}{} \\
\hline
\end{tabular}

The question of willingness to change was based on Kurt Lewin's theory of change (1951) and the model of readiness to Change (Armenakis et al. 1993). The questionnaire was selected based on its ability to met the criteria for measuring individual readiness, had positive and negative dimension questions to reduce bias, was easy to understand, concise, and had good validity and reliability. 
Moreover, the widespread use of this questionnaire (Andersen Lisbeth, 2008; Duxbury \& Higgins, 2009; Ilyas, 2018) further enhances the validity and reliability of this instrument.

Before the real study, the pilot test was carried out among selected primary and secondary schools at Kota Baharu District. A total of 120 teachers represent the test. The results of the pilot test revealed that the value of Cronbach Alpha which is referred to as a measure of "internal consistency" reliability (Bonett \& Wright, 2015) shows overall alpha value is more than 0.7 which is good considering that 0.70 is the cut-off value for being acceptable (Nunnaly, 1978). Table 2 shows in detail the results of the pilot test according to the construct.

Table 2: Dimensions, numbers of questions and numbers of the items of Individual Change Readiness

\begin{tabular}{lcc}
\hline Dimensions & Numbers of Items & Cronbach Alpha \\
\hline Change self-efficacy & 6 & 0.766 \\
Discrepancy & 3 & 0.714 \\
Personal valence (6) & 6 & 0.724 \\
Organizational valence & 10 & 0.785 \\
\hline IndividualChange Readiness & $\mathbf{2 5}$ & $\mathbf{0 . 9 1 3}$ \\
\hline
\end{tabular}

\section{Data analysis}

The study used SPSS version 25 for data analysis and AMOS 25.0 for the advanced analysis involving (SEM). Since the multivariate technique is the power to analyze the measurement model thus confirmatory factor analysis (CFA) was used to validate the model in terms of convergent validity and construct reliability (Hair et al., 2014). There were three types of measures involved in confirmatory factor analysis, i.e., Test for Model Fit, Convergent validity, Construct reliability (Bentler \& Bonett, 1980; Byrne, 2013; Hair et al., 2014).

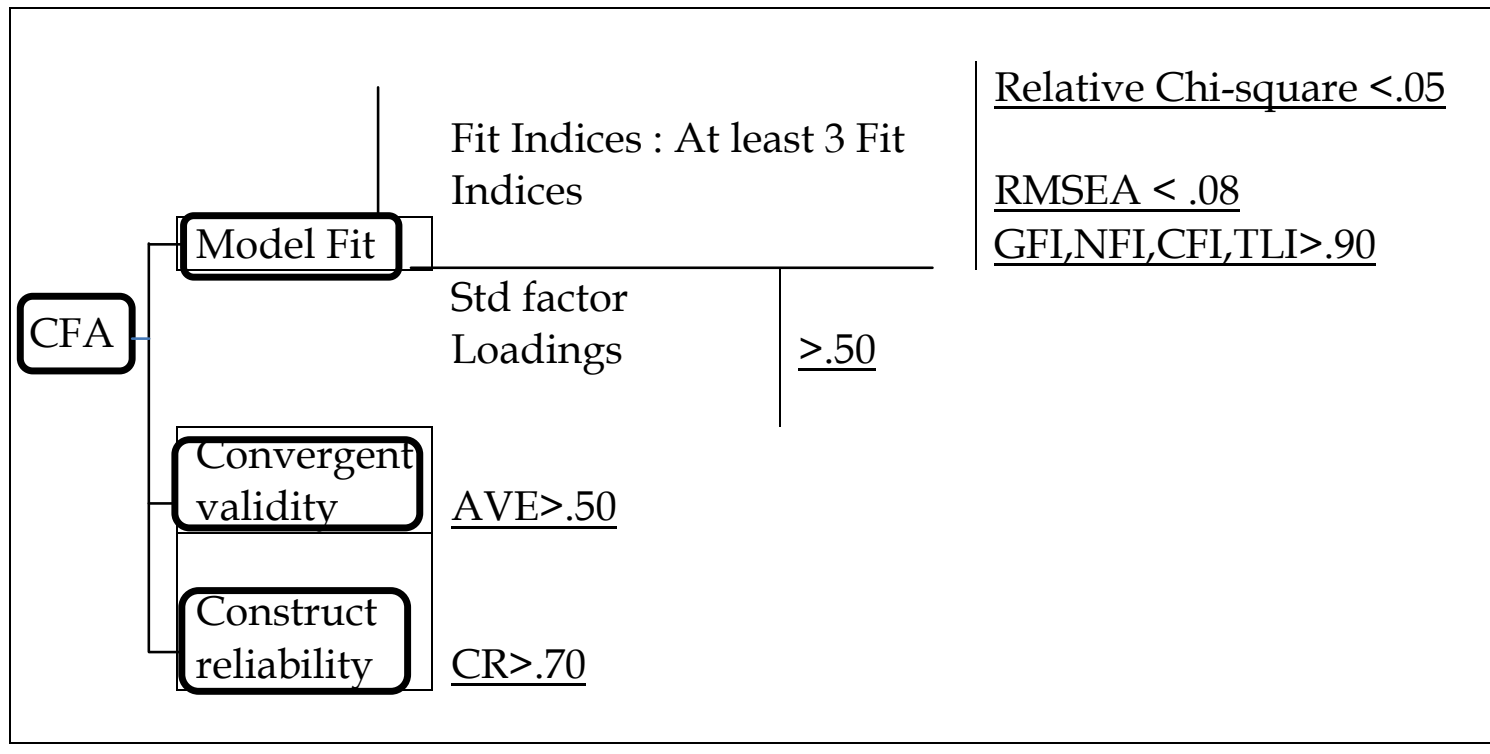

Figure: 3: An overview of Confirmatory Factor Analysis (CFA) for this study 


\section{Results}

Table 3 shows the demographic information of the respondents obtained from descriptive analysis using IBM SPSS version $25.0(\mathrm{~N}=383)$

\begin{tabular}{lcc}
\hline \multicolumn{1}{c}{ Demographic } & $\mathbf{n}$ & $\%$ \\
\hline Types of School & 199 & 52.0 \\
Primary & 184 & 48.0 \\
Secondary & & \\
\hline Area & 166 & 43.3 \\
Urban & 217 & 56.7 \\
Rural & & \\
\hline State & 130 & 33.9 \\
Kelantan & 126 & 32.8 \\
Terengganu & 127 & 33.1 \\
Pahang & & \\
\hline Gender & 187 & 48.8 \\
Male & 196 & 51.2 \\
Female & & \\
\hline Qualification & 14 & 3.7 \\
Certificate & 32 & 8.4 \\
Diploma in education & 306 & 79.9 \\
Degree & 31 & 8.1 \\
Masters & & 15.9 \\
Years of Service & 61 & 36.6 \\
1-10 years & 140 & 44.6 \\
11-20 years & 171 & 2.9 \\
21-30 years & 11 & \\
>30 years & &
\end{tabular}

Table 3 shows the distribution of demographic characteristics of the respondents in this study. The result shows that 199 (52.0\%) respondents represented the national primary school, while $184(48.0 \%)$ respondents represented the national secondary school. Response distribution based on school location indicates that rural schools dominate the school location category. A total of $217(56.7 \%)$ respondents were employed in rural schools, while 166 (43.3\%). On the other hand, the number of respondents based on the three states did not differ significantly from each other. Instead, it is within the range of 30 to $35 \%$. Respondents from Kelantan were 131 (34.2\%), Terengganu was 135 (35.2\%), while Pahang was 117 (30.5\%). Besides, the distribution in terms of gender, it was found that the number of female respondents exceeded the number of male respondents. The total number of male respondents was $187(48.8 \%)$ compared to the number of female respondents, which was 196 (51.2\%).

Besides, the findings from Table 3 also indicate that $158(41.3 \%)$ of respondents from the age group of 41-50 years dominated the study. $23(6.0 \%)$ were between the ages of 21-30, $99(25.8 \%)$ were between the ages of 31 and 40, while 50 and above were 103 (26.9\%). Meanwhile, the proportion of respondents according to academic qualification found that the number of respondents with a bachelor's degree qualified to dominate the overall demographic factors of the academic 
qualification of the respondents. A total of $31(8.1 \%)$ had at least a bachelor's degree, $306(79.9 \%) ; 32$ people $(8.4 \%)$ had pre-university qualifications while fourteen (14) $(3.7 \%)$ had at least a college certificate. The distribution of respondents in terms of teaching experience revealed that 61 respondents $(15.9 \%)$ had work experience as teachers for less than ten years. While the number of experienced respondents taught more than ten years, each 140 (36.6\%) experienced between 11 to 20 years, 171 (44.6\%) between 21-30 years, and $11(2.9 \%)$ experienced more than 30 years. Overall, teachers with 21 to 30 years of work experience were significantly higher in terms of several respondents compared to other teacher service periods.

Table 4: Descriptive Statistics Of Change Readiness Among Malaysian School Teachers

\begin{tabular}{lcccc}
\hline Construct & No of items & Mean & $\begin{array}{c}\text { Std. } \\
\text { Deviation }\end{array}$ & Level \\
\hline Change self-efficacy & 6 & 5.5226 & .65716 & (3) High \\
Discrepancy & 3 & 5.5135 & .83987 & (4) High \\
Personal Valence & 6 & 5.7032 & .68684 & (1) High \\
Organizational Valence & 10 & 5.5394 & .60403 & (2) High \\
\hline
\end{tabular}

Notes: Level=Low (1-2.33);Medium (2.34-4.67); High (4.68-7.00)

Based on the findings of the descriptive statistics of the study as in table 4, generally, Malaysian school teachers had demonstrated a high level of change readiness. The highest score of individual change readiness was personal valence $(\mathrm{M}=5.7032, \mathrm{SD}=0.68684)$, while the lowest was discrepancy $(\mathrm{M}=$ 5.5226 , SD 0.65716). However, organizational valence and change self-efficacy were considered in a high category that falls within the range of $(\mathrm{M}=5.5226$ to $5.5394)$.

\section{Findings and Discussions}

Confirmatory factor analysis was used to determine the compatibility of the measurement model to measure the relationship between constructs. IBM SEM Amos Version 25.0 was used to analyze the data obtained. Figure 4 shows the CFA output of the original measurement model hypothesized. Several compatibility indices are generated to determine the measurement model. The fit of the measurement model is essential and needs to be determined in advance, and if the measurement does not match the data, then the built-in structural equation (SEM) model is invalid (Byrne, 2013). 


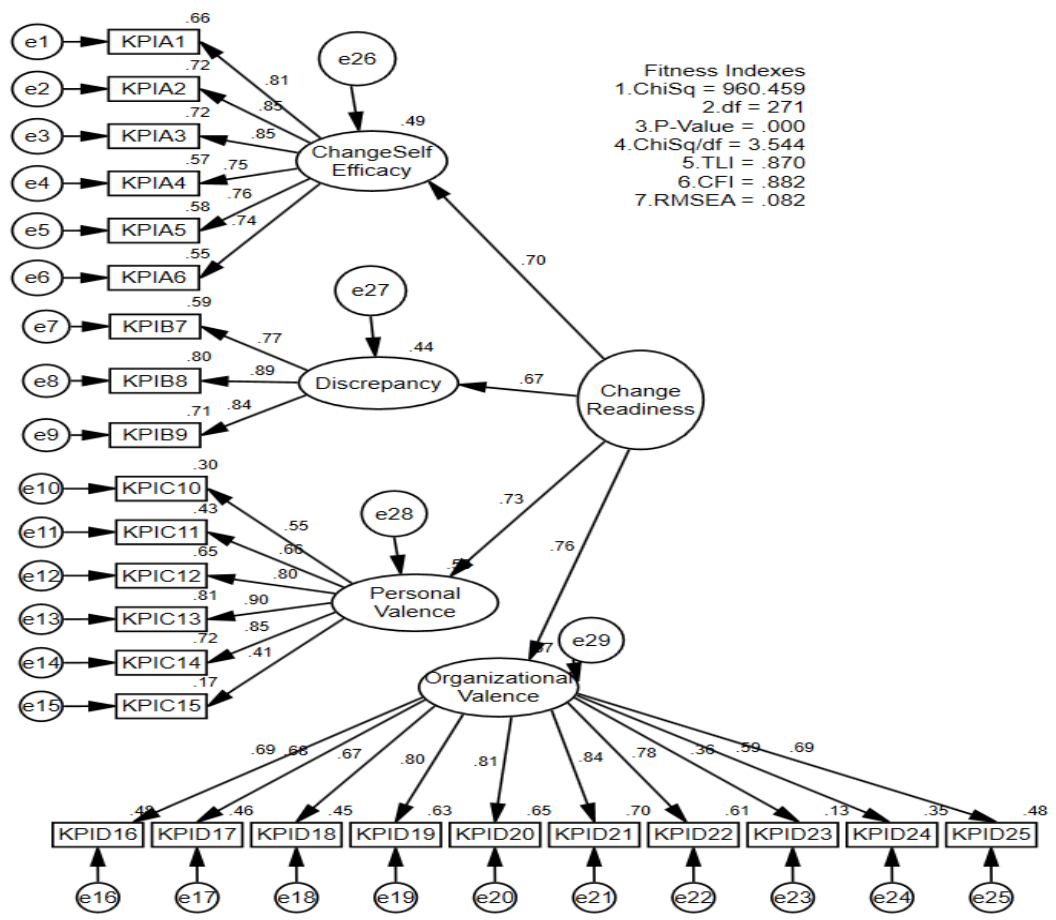

Figure 4: Original Second-order measurement model for Level of Change Readiness

According to Hair et al. (2014) measurement models need to reach one of the model's compatibility categories, Absolute Fit (see (Browne \& Cudeck, 1992) Incremental Fit (see Bentler, (1980) and Parsimonious Fit) (see Marsh \& Hocevar (1985) ). The measurement model does not achieve good Goodness of fit Indices value. Besides, there are also items with low factor loading, which is less than 0.50, as suggested by (Hair et al., 2014). Items, i.e., KPID 23, KPID 24, KPIC10, KPIC 15, were identified with low factor loading. The diagram below shows the Goodness of fit Indices values after delete items with a low factor loading.

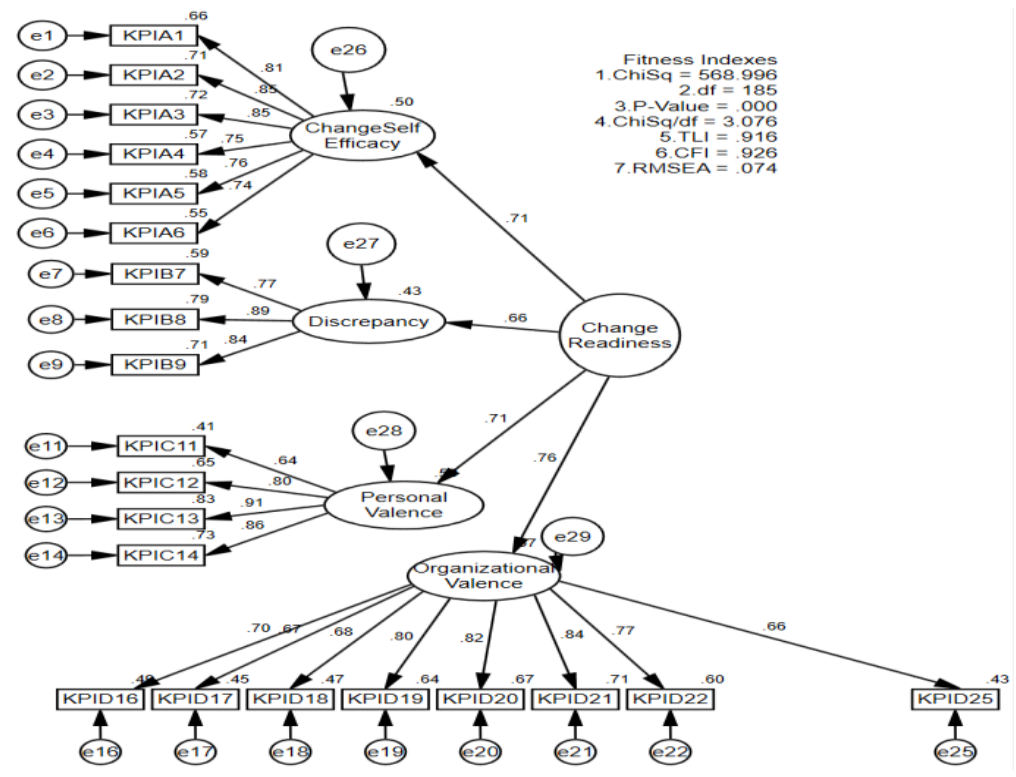

Figure 5: Final measurement model for Level of Change Readiness Among Malaysian School Teacher 
All four values of Goodness- of -fit Indices (CFI) (0.926), RMSEA (.074), TLI (.0916), ChiSq / df (3.076). All revised index fit values are CFI, TLI, ChiSq/df has increased after the elimination of the problematic item. The table shows the results of the internal reliability and convergent validity of the constructs and sub-constructs in the model. Convergence validity is assessed based on factor loadings, average extracted variance (AVE variance extracted), and composite reliability (composite reliability-CR) (Awang, Hui, 2018; Byrne, 2013; Hair et al., 2014). The measurement model of all four change readiness construct was assessed in order to ascertain the reliability and validity before the evaluation for the structured model. Table 5 provides the result of construct reliability.

Thus, based on the above measurement model results, the reliability of the four change readiness constructs was determined by using composite reliability assessment. As recommended by Hair et al., (2014) the construct reliability attains when the value of internal consistency reliability is above 0.70 . In this regard, the results of composite reliability in Table 5 suggested that the four change readiness constructs had a reliability value higher than the minimum required threshold of 0.70 . The values are ranged from 0.87 to 0.91 .

Table 5: Results of Measurement Model

\begin{tabular}{|c|c|c|c|c|}
\hline Construct & Item & Factor Loading & AVE & CR \\
\hline \multirow[t]{6}{*}{ Change self-efficacy } & KPIA1 & 0.81 & 0.63 & 0.91 \\
\hline & KPIA2 & 0.85 & & \\
\hline & KPIA3 & 0.85 & & \\
\hline & KPIA4 & 0.75 & & \\
\hline & KPIA5 & 0.76 & & \\
\hline & KPIA6 & 0.74 & & \\
\hline \multirow[t]{3}{*}{ Discrepancy } & KPIB7 & 0.77 & 0.69 & 0.87 \\
\hline & KPIB8 & 0.89 & & \\
\hline & KPIB9 & 0.84 & & \\
\hline \multirow[t]{6}{*}{ Personal valence } & KPIC10 & Item deleted & 0.65 & 0.88 \\
\hline & KPIC11 & 0.64 & & \\
\hline & KPIC12 & 0.80 & & \\
\hline & KPIC13 & 0.91 & & \\
\hline & KPIC14 & 0.86 & & \\
\hline & KPIC15 & Item deleted & & \\
\hline \multirow[t]{10}{*}{ Organizational valence } & KPID16 & 0.70 & 0.56 & 0.91 \\
\hline & KPID17 & 0.67 & & \\
\hline & KPID18 & 0.68 & & \\
\hline & KPID19 & 0.80 & & \\
\hline & KPID20 & 0.82 & & \\
\hline & KPID21 & 0.84 & & \\
\hline & KPID22 & 0.77 & & \\
\hline & KPID23 & Item deleted & & \\
\hline & KPID24 & Item deleted & & \\
\hline & KPID25 & 0.66 & & \\
\hline
\end{tabular}

Note: $A V E=$ Average Variance Extracted, $C R=$ Composite Reliability

In ascertaining convergent validity, average variance extracted (AVE) value was used. As recommended by Bagozzi and Yi (1988), Hair et al. (2014) that the 
minimum acceptable AVE value must be 0.50 and above, the AVE results in Table 5 revealed that all the four change readiness constructs had attained the minimum verge. Furthermore, Fornell and Larcker (1981) criterion were employed in determining that discriminant validity. The Fornell and Larcker (1981) criterion proposed that discriminant validity is attained when the AVE of study constructs is statistically significant and also recorded a value higher than its squared correlation with other latent variables. This study accepted the Fornell and Larcker (1981) criterion in ascertaining the discriminant validity of the model.

Table 6: Discriminant Validity

\begin{tabular}{|l|c|c|c|c|}
\hline & $\begin{array}{l}\text { Change } \\
\text { self- } \\
\text { efficacy }\end{array}$ & Discrepancy & $\begin{array}{l}\text { Personal } \\
\text { valence }\end{array}$ & $\begin{array}{l}\text { Organizational } \\
\text { valence }\end{array}$ \\
\hline Change self-efficacy & $\mathbf{0 . 7 9}$ & & & \\
\hline Discrepancy & 0.28 & $\mathbf{0 . 8 3}$ & & \\
\hline Personal valence & 0.18 & 0.25 & $\mathbf{0 . 8 0}$ & \\
\hline $\begin{array}{l}\text { Organizational } \\
\text { valence }\end{array}$ & 0.31 & 0.18 & 0.34 & $\mathbf{0 . 7 5}$ \\
\hline
\end{tabular}

The above results in Table 6 suggested that the squared root values of four change readiness constructs (bolded) are higher than the correlation among the variables, thus indicating discriminant validity is attained. As a result of the CFA, the sub-construct of change readiness, namely change self-efficacy, discrepancy, personal valence, and organizational valence, mutually fit without any multicollinearity problem. Therefore, it can be concluded that the validity of the four constructs has been achieved. After modifications to the model were done by eliminate items with low factor loading and meet the desired validity and reliability of the model, it can be determined that there is a consistent model of change readiness among school teachers with the available survey data. Thus, hypotheses $H 1$ were supported. Twenty-one items were retained in the model and were able to measure the level of readiness of individual teacher change in the educational context. As this study is the first study conducted on school teachers to determine the change readiness to become a competent teacher, researchers have trouble finding relevant literature that can directly support the findings of this study. However, most of the research which was done in the field of management is backed up by this study.

The findings of this study were in congruence with Adil (2016), Anjani and Dhanapal (2012), Mua'azam Mohamad (2016), Vakola (2014), all of whom had discovered there is high level of change readiness among individuals in a organization to support the new change initiatives. Fullan (2007), Karp and Helgo (2008) found that the willingness to change is always ineffective without the support of leaders in the organization. The findings of this study support this statement where administrative support is significant in the readiness of individual change

This study is important because change is taking place in the education system globally. Teachers are a vital element in developing a balanced human model 
through the national education system. The main aim of the Malaysian Education Development Plan (PPPM) (2013-2025) is to make Malaysia outstanding among other developed countries, and that will only be achieved by competent educators (MOE, 2013). Competent teachers in terms of knowledge, skills, and attitudes can produce a balance of physical, Emotional, Spiritual, and Intellectual Capital (National Philosophy of Education, FPK). Readiness to accept changes in education helps a teacher apply 21st-century learning.

\section{Implications and Contributions}

Theoretically, this study enables to successfully produce a four-factor model of change readiness among Malaysian school teachers. Thus, to confirm the fourfactor model for this study, qualitative evaluation of the model should be carried out, and it will be the next phase of exploration in this area of study. The findings of this study might help the Ministry of education, district offices, and schools to know about the importance of change readiness among school teachers. According to MacCallum, Wegener, Uchino and Fabriga (1993) there may be other alternative models that use different sub-constructs with similarities to the same data. Thus, future studies are encouraged to test the existence of other alternative models and to compare them with the original model to help make improvements to the original model.

\section{Conclusion}

This study's findings disclose the ongoing opportunity for change researchers to investigate the issue of change readiness among school teachers, which remains an inevitable issue that should take into consideration. The results show an essential element in change management strategy, whereas change readiness plays a vital role in whether teachers ready for change and extend theory and research on the importance of change readiness among teachers in educational settings. Also, there were several works of literature reported that there is high level of relationship between change readiness, i.e., change self-efficacy (Cunningham et al., 2002; Kwahk \& Lee, 2008; Rafferty \& Simons, 2006) organizational commitment (Kwahk \& Kim, 2008; Kwahk \& Lee, 2008; Madsen, Miller, \& John, 2005) perceived personal competence (Kwahk \& Kim, 2008). Hence, based on the data and contemporary studies, change readiness had a significant impact on change implementation, and it is critical for educational transformation change's success. As has been noted, the individual change readiness in an educational setting, especially to develop competence among school teachers, was found one of the most exceptional contributions to the existing theory.

Changes in education will be more successful if the concern of change recipients (teachers) is considered. Educational transformation cannot be successful unless teachers ready to change. Teacher's readiness to accept the changes that happened in education is a big challenge for the Ministry of education, but this issue frequently neglected in planning and implementing new issues (Backer, David, \& Soucy, 1995). By identifying specific change, readiness features can help the Ministry of education to direct and implement more new ideas to 
empower the Malaysian education system. Hence, the concept of individual change readiness for educational change should pay attention.

\section{Limitations and Further Research}

Future research may test the hypothesis that other-focused teachers change readiness and the relationship between school climate and students' achievements. We also admit the limits of our study design. Forthcoming studies may use longitudinal, diary studies rather than cross-sectional to prevent the existence of common method variance.

\section{References}

Adil, M. S. (2016). Impact of change readiness on commitment to technological change, focal, and discretionary behaviors: Evidence from the manufacturing sector of Karachi. Journal of Organizational Change Management, 29(2), 222-241. https:// doi.org/10.1108/JOCM-11-2014-0198

Andersen, L. (2008). Readiness for change: Can readiness be primed?(Unpublished master's thesis). San Jose State University, California, United States. Retrieved from https://scholarworks.sjsu.edu/etd_theses/3517 https:// doi.org/10.31979/etd.pnn8-n98c

Anjani, P., \& Dhanapal, D. (2012). Impact of employee commitment on readiness for change in banking sector in Salem district. Global Management Review, 6(3), 24-34.

Armenakis, A. A., Harris, S. G., \& Mossholder, K. W. (1993). Creating readiness for organizational change. Human Relations, 46(6), 681-703. https://doi.org/10.1177/001872679304600601

Awang, Z., Lim S. H., \& Zainudin, N. F. S. (2018). Pendekatan mudah SEM:Structural equation modeling ( $1^{\text {st }}$ ed.). Bandar Baru Bangi, Malaysia: MPWS Rich Publication.

Backer, T. E., David, S. L., \& Soucy, G. (1995). Assessing and enhancing readiness for change: Implications for technology transfer. NIDA research monograph, 155, 2141. https://doi:10.1037/e495742006-003

Bagozzi, R. P., \& Yi, Y. (1988). On the evaluation of structural equation models. Journal of the Academy of Marketing Science 16(1), 74-94. https://doi.org/10.1007/BF02723327

Beaton, D. E., Bombardier, C., Guillemin, F., \& Ferraz, M. B. (2000). Guidelines for the process of cross-cultural adaptation of self-report measures. Spine, 25(24), 31863191.

Bentler, P. M., \& Bonett, D. G. (1980). Significance tests and goodness of fit in the analysis of covariance structures. Psychological Bulletin, 88(3), 588-606. https://doi.org/10.1037/0033-2909.88.3.588

Berger, B. A., \& Hudmon, K. S. (1997). Readiness for change: Implications for patient care. Journal of the American Pharmaceutical Association, 37(3), 321-329. https:// doi.org/10.1016/s1086-5802(16)30218-2

Bonett, D. G., \& Wright, T. A. (2015). Cronbach's alpha reliability: Interval estimation, hypothesis testing, and sample size planning. Journal of Organizational Behavior, 36(1), 3-15. https://doi.org/10.1002/job.1960

Brislin, R. W., Lonner, W., \& Thorndike, R. M. (1973). Cross-cultural research methods. New York: John Wiley. https://doi.org/10.1177/135910457000100301

Browne, M. W., \& Cudeck, R. (1992). Alternative ways of assessing model fit. Sociological $\begin{array}{llll}\text { Methods } \& \text { Research, 230-258. } & \text { 21(2), }\end{array}$ https:// doi.org/10.1177/0049124192021002005 
Byrne, B. M. (2013). Structural equation modeling with Mplus: Basic concepts, applications, and programming. New York, London: Routledge.

Cinite, I., Duxbury, L. E., \& Higgins, C. (2009). Measurement of perceived organizational readiness for change in the public sector. British Journal of Management, 20(2), 265-277. https://doi.org/10.1111/j.1467-8551.2008.00582.x

Creswell, J. W. (2014). Research design: Qualitative, quantitative, and mixed methods approaches. (4th ed.). Thousand Oaks, CA: Sage https://doi.org/10.1007/s13398014-0173-7.2

Cunningham, C. E., Woodward, C. A., Shannon, H. S., Macintosh, J., Lendrum, B., Rosenbloom, D., \& Brown, J. (2002). Readiness for organizational change: A longitudinal study of workplace, psychological, and behavioural correlates. Journal of Occupational \& Organizational Psychology, 75(4), 377-392. https:// doi:10.1348/096317902321119637

Darling-Hammond. (2017). Teacher education around the world: What can we learn from international practice?. European Journal of Teacher Education, 40(3), 291-309. https:// doi.org/10.1080/02619768.2017.1315399

Fornell, C., \& Larcker, D. F. (1981). Structural equation models with unobservable variables and measurement error: Algebra and statistics. Journal of Marketing Research, 18(3), 382-388. https://doi.org/10.1177/002224378101800313

Fullan, M. 2007. The New Meaning of Educational Change. New York: Teachers College Press. https:/ / doi:10.4324/9780203986561

Haffar, M., Al-Karaghouli, W., \& Ghoneim, A. (2013). The mediating effect of individual readiness for change in the relationship between organisational culture and TQM implementation. Total Quality Management and Business Excellence, 24(5-6), 693-706. https://doi.org/10.1080/14783363.2013.791112

Hair, J. F., Black, W. C., Babin, B. J., \& Anderson, R. E. (2014). Multivariate Data Analysis (7th ed.). Harlow, UK: Pearson Education Limited. https://doi.org/10.1007/978 3-319-01517-0_3

Hinton, S. (2018). How the fourth industrial revolution is impacting the future of work Foebes.

Retrieved

from https://www.forbes.com/sites/theyec/2018/10/19/how-the-fourth-industrialrevolution-is impacting-the -future-of-work/

Holt, D. T., Armenakis, A. A., Feild, H. S., \& Harris, S. G. (2007). Readiness for organizational change: The systematic development of a scale. Journal of Applied Behavioral Science, 43(2), 232-255. https:/ / doi.org/10.1177/0021886306295295

Ilyas, M. (2018). Investigating readiness for acceptance of change for the adoption of blackboard Ims at Prince Sattam bin Abdulaziz University, Saudi Arabia. International Journal of Education and Practice, 6(4), 216-226. https://doi.org/10.18488/journal.61.2018.64.216.226

Iqbal, A., \& Asrar-ul-Haq, M. (2018). Establishing relationship between TQM practices and employee performance: The mediating role of change readiness. International Journal of Production Economics, 203, 62-68. https://doi.org/10.1016/j.ijpe.2018.05.034

Karp, T., \& Helgo, T. (2008). The future of leadership: The art of leading people in a post managerial environment. Foresight, 10(2), 30-37. https:/ / doi.org/10.1108/14636680810869662

Kementerian Pendidikan Malaysia (2013). Pelan pembangunan pendidikan Malaysia 2013 2025: Pendidikan prasekolah hingga lepas menengah [Malaysia education development plan 2013 2025: Preschool education through secondary]. Putrajaya; Kuala Lumpur.

Kwahk, K.., \& Lee, J. (2008). The role of readiness for change in ERP implementation: Theoretical bases and empirical validation. Information $\mathcal{E}$ Management, 45(7), 
474-481. https:// doi.org/10.1016/j.im.2008.07.002

Kwahk, K. Y., \& Kim, H. W. (2008). Managing readiness in enterprise systems-driven organizational change. Behaviour and Information Technology, 27(1), 79-87. https://doi.org/10.1080/01449290701398475

MacCallum, R. C., Wegener, D. T., Uchino, B. N., \& Fabrigar, L. R. (1993). The problem of equivalent models in applications of covariance structure analysis. Psychological Bulletin, 114(1), 185-199. https:// doi.org/10.1037/0033-2909.114.1.185

Madsen, S. R., Miller, D., \& John, C. R. (2005). Readiness for organizational change: Do organizational commitment and social relationships in the workplace make a difference? Human Resource Development Quarterly, 16(2), 213-234. https://doi.org/10.1002/hrdq.1134

Mangundjaya, W. H., \& Gandakusuma, I. (2013). The role of leadership \& readiness for change to commitment to change. Romanian Economic and Business Review, 8(4.1), 192-197.

Marsh, H. W., \& Hocevar, D. (1985). Application of confirmatory factor analysis to the study of self-concept: First-and higher-order factor models and their invariance across groups. Psychological Bulletin, 97(3), 562. https://doi:10.1037/00332909.97.3.562

Mua'azam Mohamad. (2016). Pengaruh kepimpinan strategik dan kesediaan perubahan organisasi terhadap amalan penambahbaikan kualiti berterusan di sekolah agama [Influence of strategic leadership and organizational change readiness on the practice of continuous quality improvement in religious schools]. (Unpublished doctoral dissertation). University Utara Malaysia.

Neves, P. (2009). Readiness for change: Contributions for employee's level of individual change and turnover intentions. Journal of Change Management, 9(2), 215-231. https:// doi.org/10.1080/14697010902879178

Nunnaly, J. (1978). Psychometric theory (2nd ed.). New York: McGraw-Hill.

Rafferty, A. E., \& Simons, R. H. (2006). An examination of the antecedents of readiness for fine-tuning and corporate transformation changes. Journal of Business and Psychology, 20(3), 325-350. https:// doi.org/10.1007/s10869-005-9013-2.

Sawitri, H. S. R., \& Wahyuni, S. (2018). Readiness to change in the public sector. International Journal of Business and Society, 19(1), 259-267.

Schunk, D. H., \& Dibenedetto, M. K. (2016). Self-efficacy theory in education. In Wentzel. K. R., Miele. D. B (Eds.), Handbook of motivation at school (2nd ed.,pp. 34-54). New York, London: Routledge. https://doi.org/10.4324/9781315773384.ch3

Schwab, K., \& Davis, N. (2018). Shaping the future of the fourth industrial revolution: A guide to building a better world. Geneva: World Economic Forum

Vakola, M. (2014). What 's in there for me? Individual readiness to change and the perceived impact of organizational change. Leadership $\mathcal{E}$ Organization Development Journal, 35(3), 195-209. https://doi.org/10.1108/LODJ-05-2012-0064 